Neuro Images
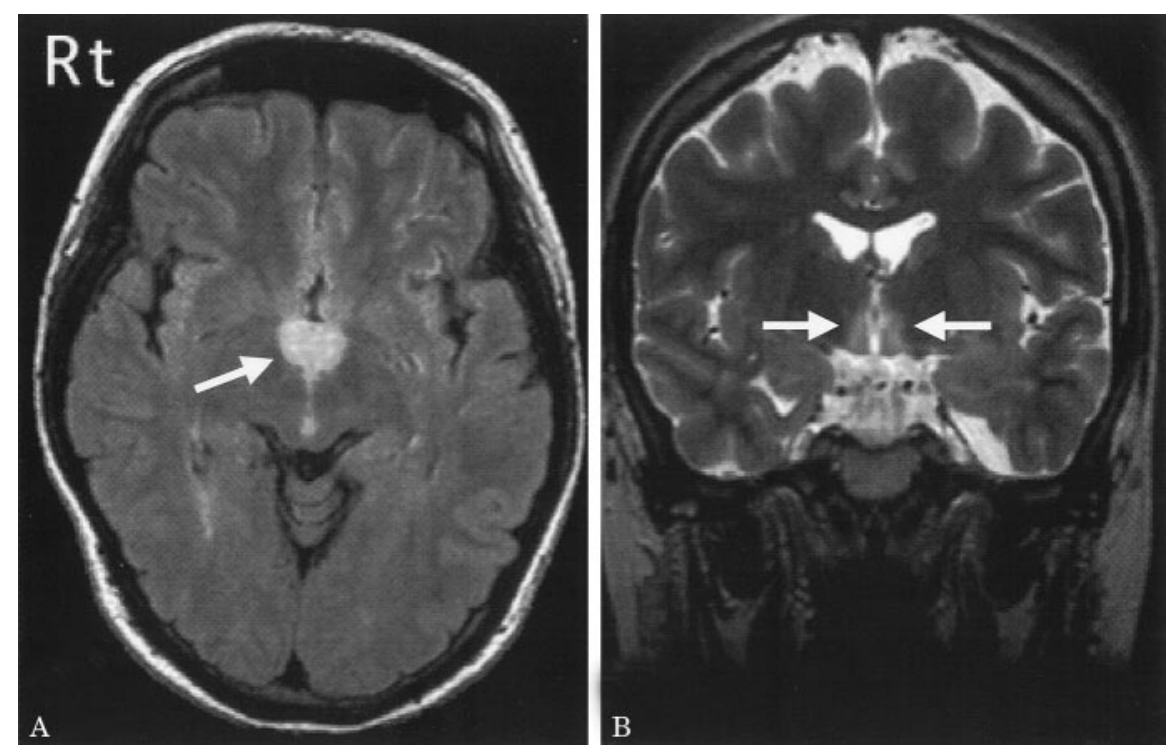

Figure. Axial section (A) of fluidattenuated inversion-recovery (FLAIR) image and coronal section $(B)$ of T2weighted image. Bilateral hypothalamic plaque is demonstrated as a median high intensity area (arrow).

\section{Hypersomnia in MS}

K. Iseki, MD, T. Mezaki, MD, PhD, Y. Oka, MD,

$K$. Terada, $M D, P h D, H$. Tomimoto, $M D, P h D$,

Y. Miki, MD, PhD, H. Shibasaki, MD, PhD, Kyoto, Japan

Focal lesions can cause narcolepsy.1,2 A 22-year-old woman with MS developed acute hypersomnia. Her first episode of MS occurred 9 months previously, when she presented with internuclear ophthalmoplegia and left

Address correspondence and reprint requests to Dr. Takahiro Mezaki, Department of Neurology, Kyoto University Hospital, 54 Shogoin-Kawaharacho, Sakyo-ku, Kyoto 606-8507, Japan; e-mail: tamezaki@kuhp.kyoto-u.ac.jp homonymous hemianopsia; this episode reversed. She did not have sleep paralysis, hypnagogic hallucinations, or cataplexy. Brain MRI (figure) showed a new plaque via tuber cinereum through bilateral hypothalamus, in addition to multiple plaques in other regions but not in the brainstem. Because orexin was undetectable $(<40 \mathrm{pg} / \mathrm{mL})$ in the CSF, we presume that this hypothalamic plaque caused hypersomnia, which improved in several weeks.

1. Silber MH, Rye DB. Solving the mysteries of narcolepsy: the hypocretin story. Neurology 2001;56:1616-1618.

2. Malik S, Boeve BF, Krahn LE, Silber MH. Narcolepsy associated with other central nervous system disorders. Neurology 2001;57:539-541. 


\title{
Neurology
}

\author{
Hypersomnia in MS \\ K. Iseki, T. Mezaki, Y. Oka, et al. \\ Neurology 2002;59;2006-2007 \\ DOI 10.1212/01.WNL.0000042784.84142.12
}

This information is current as of December 24, 2002

Updated Information \& Services

References

Subspecialty Collections

Permissions \& Licensing

Reprints including high resolution figures, can be found at: http://n.neurology.org/content/59/12/2006.full

This article cites 2 articles, 2 of which you can access for free at: http://n.neurology.org/content/59/12/2006.full\#ref-list-1

This article, along with others on similar topics, appears in the following collection(s):

All Sleep Disorders

http://n.neurology.org/cgi/collection/all_sleep_disorders

MRI

http://n.neurology.org/cgi/collection/mri

Multiple sclerosis

http://n.neurology.org/cgi/collection/multiple_sclerosis

Other hypersomnias

http://n.neurology.org/cgi/collection/other_hypersomnias

Information about reproducing this article in parts (figures,tables) or in its entirety can be found online at:

http://www.neurology.org/about/about_the_journal\#permissions

Information about ordering reprints can be found online:

http://n.neurology.org/subscribers/advertise

Neurology ${ }^{\circledR}$ is the official journal of the American Academy of Neurology. Published continuously since 1951, it is now a weekly with 48 issues per year. Copyright . All rights reserved. Print ISSN: 0028-3878. Online ISSN: 1526-632X.

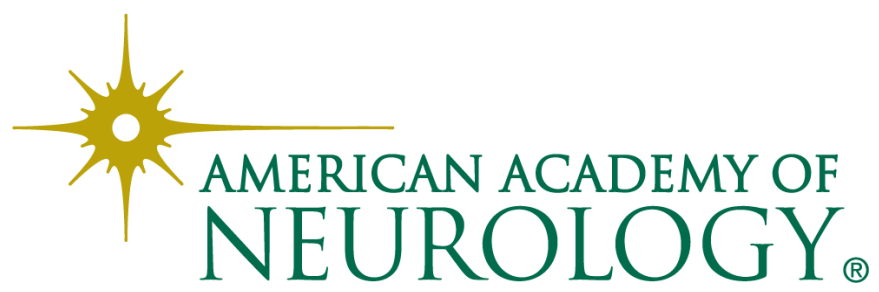

